\title{
Storage of sunflower seeds ${ }^{1}$
}

\author{
Armazenamento de sementes de girassol
}

\author{
Denise de Castro Lima², Alek Sandro Dutra ${ }^{3 *}$, Felipe Moura Pontes ${ }^{2}$ e Francisco Thiago Coelho Bezerra ${ }^{2}$
}

\begin{abstract}
The sunflower is among the top five crops in the world for the production of edible vegetable oil. The species displays rustic behavior, with an excellent edaphic and climatic adaptability index, being able to be cultivated throughout Brazil. Seed quality is the key to increasing production and productivity in the sunflower. The objective of this work was to monitor the viability of sunflower seeds with a view to their conservation when stored in different environments and packaging. The seeds were packed in paper bags, multilayered paper, black polyethylene and PET bottles; and stored for a period of twelve months in the following environments: dry cold room $\left(10{ }^{\circ} \mathrm{C}\right.$ and $\left.55 \% \mathrm{RH}\right)$, the ambient conditions of Fortaleza, Ceará, Brazil $\left(30-32{ }^{\circ} \mathrm{C}\right.$ and $\left.75 \% \mathrm{RH}\right)$, refrigerator $\left(4{ }^{\circ} \mathrm{C}\right.$ and $\left.38-43 \% \mathrm{RH}\right)$ and freezer $\left(-20{ }^{\circ} \mathrm{C}\right)$. Every three months, the water content of the seeds was determined and germination, accelerated ageing, speed of emergence index, and seedling dry weight were evaluated. The experimental design was completely randomized, in a scheme of split-lots, with four replications. It can be concluded that the natural environment is not suitable for the storage of sunflower seeds. Sunflower seeds remain viable for 12 months when stored in a dry cold room, refrigerator or freezer, irrespective of the type of packaging used.
\end{abstract}

Key words: Helianthus annus L.. Packaging. Viability.

RESUMO - O girassol está entre as cinco maiores culturas produtoras de óleo vegetal comestível no mundo. É uma espécie de comportamento rústico e seu índice de adaptabilidade edafoclimático é excelente, podendo no Brasil, ser cultivado de Norte a Sul. A qualidade da semente é a chave para o incremento da produção e produtividade do girassol. Objetivou-se com este trabalho monitorar a viabilidade das sementes de girassol armazenadas em diferentes ambientes e embalagens visando a sua conservação. As sementes foram acondicionadas em embalagens de saco papel, papel multifoliado, polietileno preto e garrafa pet e armazenadas por um período de doze meses nos ambientes de: câmara fria e seca $\left(10^{\circ} \mathrm{C}\right.$ e $55 \%$ UR), em condições ambientais de Fortaleza-CE $\left(30-32{ }^{\circ} \mathrm{C}\right.$ e $\left.75 \% \mathrm{UR}\right)$, geladeira $\left(4{ }^{\circ} \mathrm{C}\right.$ e 38 a $43 \%$ UR) e freezer $\left(-20^{\circ} \mathrm{C}\right)$. A cada três meses as sementes foram submetidas às seguintes avaliações: determinação do teor de água, germinação, envelhecimento acelerado, índice de velocidade de emergência e massa da matéria seca das plântulas. O delineamento experimental foi o inteiramente casualizado, no esquema de parcelas subsubdivididas, com quatro repetições. Conclui-se que o ambiente natural não é indicado para o armazenamento de sementes de girassol. As sementes de girassol permanecem viáveis por 12 meses quando armazenadas em câmara fria e seca, geladeira e freezer, independente do tipo de embalagem.

Palavras-chave: Helianthus annus L.. Acondicionamento. Viabilidade.

\footnotetext{
* Autor para correspondência

${ }^{1}$ Recebido para publicação em 14/12/2012; aprovado em 26/12/2013

Pesquisa realizada na Universidade Federal do Ceará como parte da Dissertação de Mestrado da primeira autora

${ }^{2}$ Programa de Pós-Graduação em Agronomia/Fitotecnia, Universidade Federal do Ceará, Caixa Postal 12.168, Campus do Pici, Fortaleza-CE,Brasil, 60.356-001,dennisedecastro@gmail.com, hamtaro_op@hotmail.com,bezerra_ftc@yahoo.com.br

${ }^{3}$ Departamento de Fitotecnia do Centro de Ciências Agrárias, Universidade Federal do Ceará, Caixa Postal 12.168, Campus do Pici, Fortaleza-CE, Brasil, 60.356-001, alekdutra@ufc.br
} 


\section{INTRODUCTION}

The sunflower (Helianthus annus L.) of the family Asteraceae, is an oilseed crop with important agronomic characteristics, showing greater resistance to drought, cold and heat than most of the species commonly grown in Brazil. It shows ample adaptability to different edaphic and climatic conditions and its yield is little influenced by latitude, altitude or photoperiod (GOMES, 2006). Among other uses, its seeds are employed to extract high-quality oil for human consumption and in the manufacture of animal feed. Due to these particularities and the growing demand from the industrial and commercial sectors, cultivation of the sunflower is becoming an important economic alternative in the systems of crop rotation, intercropping and succession in regions where grains are produced (PORTO et al., 2007).

As it is an oilseed species, its seeds lose their germinating power far more quickly, especially when stored under unsuitable conditions. Such seeds have a lower storage potential than amylaceous seeds, due to the low chemical stability of lipids in relation to starch; the temperature required for the degradation of starch is higher than that responsible for the same effect in oilseeds (MARCOS FILHO, 2005).

Storage conditions are decisive in ensuring the physiological quality of the seeds, and although their quality cannot be improved, good conditions during this time will help to keep the seeds viable for longer, slowing down the deterioration process (SEDIYAMA et al., 1981 apud ALMEIDA et al., 2010). This has resulted in seed producers being concerned with the use of techniques that may help to minimise those factors that cause deterioration.

For the better conservation of orthodox seeds such as the sunflower, environments with lower relative humidity and temperatures have proved to be suitable, since these conditions allow for a low level of chemical activity in the seeds, and the preservation of their germinating power and vigour (MARCOS FILHO, 2005). Conditions of high relative humidity can cause resumption of metabolic activity in the embryo, while high temperatures cause increased respiration and depletion of accumulated reserves (AGUIAR, 1995). The type of packaging used for storage is of great importance in preserving the viability and vigour of the seeds (GUEDES et al., 2012). The packaging used for storage should help slow the deterioration process with the aim of decreasing respiration, thus maintaining the initial moisture content of the stored seeds (TONIN; PEREZ, 2006). Proper storage can prolong the viability of the seeds and maintain a high level of vigour. Studies which seek secure conditions for the preservation of seeds, especially in terms of appropriate packaging and storage locations, are therefore of great importance. The aim of this work was to monitor the viability of sunflower seeds stored in different environments and packaging, with a view to their conservation.

\section{MATERIAL E METHODS}

This work was developed by the Seed Analysis Laboratory of the Department for Plant Science at the Federal University of Ceará (UFC) in Fortaleza, Ceará, Brazil, in 2011. For the experiment, seeds of the sunflower cultivar Catissol were used. The seeds were placed into four types of packaging: paper bags, multilayered paper, black polyethylene and PET bottles; and kept for 12 months in the following environments: dry cold room $\left(10{ }^{\circ} \mathrm{C}\right.$ and $\left.55 \% \mathrm{RH}\right)$, ambient conditions (30-32 ${ }^{\circ} \mathrm{C}$ and $\left.75 \% \mathrm{RH}\right)$, refrigerator $\left(4^{\circ} \mathrm{C}\right.$ and $38-43 \%$ $\mathrm{RH})$ and freezer $\left(-20^{\circ} \mathrm{C}\right)$.

Initially and every three months the seeds were evaluated for physiological quality using the following determinations and tests: a) water content, determined by the oven method at $105{ }^{\circ} \mathrm{C} \pm 3{ }^{\circ} \mathrm{C}$ for 24 hours with four replications of 25 seeds per treatment, the results being expressed as a percentage; b) germination test, 200 seeds being used in each treatment, with "Germitest" paper as substrate, moistened with distilled water in the ratio of 2.5 times the weight of the dry paper. Rolls of paper, each with 50 seeds, were placed into a "Biological Organism Development" (BOD) type germinator, set at $25^{\circ} \mathrm{C}$. Evaluation of germinated seeds was done on the fourth and tenth day after sowing; c) accelerated ageing, using the procedure described by Marcos Filho (1999), two hundred seeds were spread over an aluminium screen fixed in a plastic "gerbox" containing $40 \mathrm{~mL}$ of water. The boxes with the seeds, were closed and kept at $41{ }^{\circ} \mathrm{C}$ for 48 hours. At the end of 48 hours, the seeds were subjected to germination testing, with the percentage of normal seedlings being evaluated on the fourth day after sowing; d) emergence speed index, the test was done using 100 seeds per treatment, divided into four replications of 25 seeds. The seeds were sown in beds of $10.0 \times 1.0 \mathrm{~m}$, at a depth of $0.02 \mathrm{~m}$ and in rows spaced $0.15 \mathrm{~m}$ apart. Irrigation was carried out whenever necessary in order to provide water for seed germination and seedling emergence. Daily counts of emerged seedlings were taken every 24 hours for fourteen days. Seedlings where the cotyledons had emerged through the surface of the sand were counted. The index was calculated according to the formula proposed by Maquire (1962); e) seedling 
dry weight, where seedlings, taken from the last count for the emergence speed index, were placed in paper bags and put into an air flow oven at $80{ }^{\circ} \mathrm{C}$ for 24 hours and then weighed, the results being expressed in grams. The work was carried out in a completely randomised experimental design, in a scheme of split lots, with four replications. The data were subjected to regression analysis. For the factor, storage period, polynomial regression analysis was performed using the SISVAR software.

\section{RESULTS AND DISCUSSION}

Analysing the data shown in Figure 1, it can be seen that the initial water content of the seeds was $5.8 \%$ and that over the storage period there were variations in the percentage moisture content of the seeds in all the environments and packaging under study. In the natural environment the gain in moisture from after the third month of storage is noteworthy for all the packaging types that were analysed. In that environment the seeds placed in paper packaging showed the highest values for moisture content. The moisture content of the seeds fluctuates with the relative humidity through the exchange of water vapour between the seeds and the environment, since the seeds present high hygroscopic capacity (ABUD et al., 2012).

The seeds which were packaged in PET bottles and kept in the natural environment, showed a gradual increase in the percentage of moisture content, which by the end of the experiment reached $7.7 \%$ (Figure 1). It is worth noting that the increase in the water content of the seeds is due to the higher respiratory rate of seeds stored in that packaging, providing a greater release of water and increasing the relative humidity inside the package, the seeds thus seeking to adjust to the new relative humidity of the air, and consequently

Figure 1 - Water content (\%) of sunflower seeds kept in different environments and packaging during 12 months of storage

Natural enviorment

Paper $=\hat{\mathrm{y}}=5.72 * *+1.1722^{* * *} \mathrm{x}^{2}+0.008 * * \mathrm{x}^{3} \quad \mathrm{R}^{2}=0.9879$

- Multilayered paper $=\hat{\mathrm{y}}=5.67 * *+0.3746 \mathrm{x}+0.0627 \mathrm{x}^{2}+0.0031 \mathrm{x}^{3} \quad \mathrm{R}^{2}=0.8701$

$\Delta$ Black polyethylene $=\hat{\mathrm{y}}=5.68^{* *}-0.0129 * * \mathrm{x}+0.0103 * * \mathrm{x}^{2} \quad \mathrm{R}^{2}=0.9063$

$\times$ PET bottle $=\hat{y}=5.56 * *+0.153 * * x \quad R^{2}=0.8936$

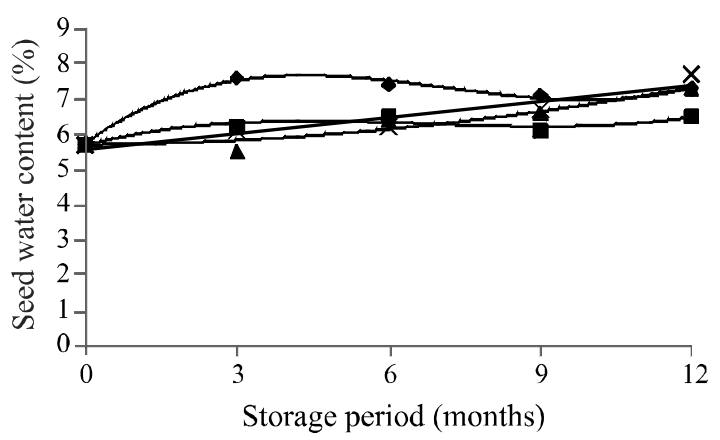

Refrigetator

- Paper $=\hat{y}=5.60 * *+1.6159 * * x-0.3532 * * x^{2}+0.0191 * * x^{3} \quad R^{2}=0.8586$

- Multilayered paper $=\hat{\mathrm{y}}=5.56^{* *}+0.2365^{* *} \mathrm{x}-0.0317^{* *} \mathrm{x}^{2}+0.0012^{* *} \mathrm{x}^{3} \mathrm{R}^{2}=0.725$

\ Black polyethylene $=\hat{y}=5.8^{* *}-0.6^{* *} \mathrm{x}+0.0889 * \mathrm{x}^{2}-0.0037 * \mathrm{x}^{3} \quad \mathrm{R}^{2}=1$

$\times$ PET bottle $=\hat{y}=5.70 * *+0.3496 * * x-0.0849 x^{2}+0.004 x^{3} \quad R^{2}=0.6891$

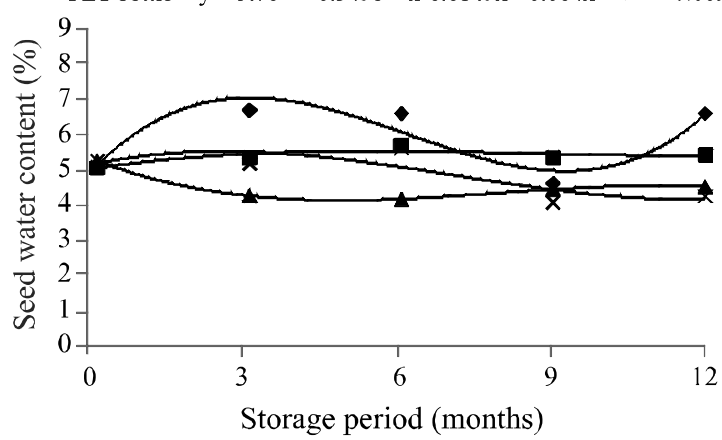

Dry cold room

- Paper $=\hat{y}=5.93^{* *}-0.1095^{* *} \mathrm{x}-0.027^{* *} \mathrm{x}^{2}+0.0037 * * \mathrm{x}^{3} \quad \mathrm{R}^{2}=0.665$

Multilaycred paper $=\hat{y}=5.95 * *-0.3984 x+0.0341 x^{2}+0.0006 x^{3} \quad R^{2}=0.6552$

$\triangle$ Black polyethylene $=\hat{\mathrm{y}}=5.87^{* *}-0.0421^{* *} \mathrm{x}-0.0238^{* *} \mathrm{x}^{2}+0.0031^{* *} \mathrm{x}^{3} \quad \mathrm{R}^{2}=0.8571$

$\times$ PET bottle $=\hat{y}=5.80 * *-0.6563 * * x+0.0913 x^{2}-0.0025 x^{3} \quad R^{2}=0.8208$

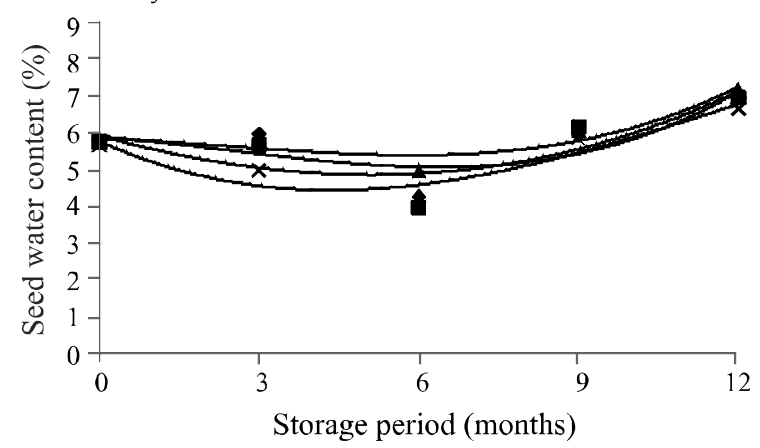

Freezer

- Paper $=\hat{y}=5.76 * *+0.1389 x+7 E-15 * x^{2}-0.0006 * * x^{3} \quad R^{2}=0.6135$

- Multilayered paper $=\hat{y}=5.75 * *+0.4357 * * x-0.0294 * x^{2}-7 E-16 x^{3} \quad R^{2}=0.6552$

$\triangle$ Black polyethylene $=\hat{y}=5.61^{* *}+0.3504^{*} x-0.0429 x^{2}+0.0015 x^{3} \quad R^{2}=0.9546$

$\times$ PET bottle $=\hat{y}=5.56^{* *+0.9869 * *} x-0.1802 * * x^{2}+0.0083 x^{3} \quad R^{2}=0.9596$

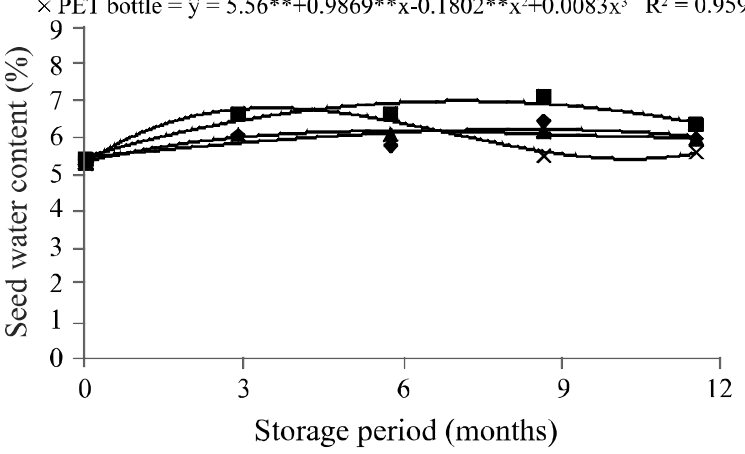


aquiring a water content that will be greater than the initial amount (CARVALHO; NAKAGAWA, 2000). In the dry cold room, the seeds absorbed water from the environment, increasing their water content (Figure 1). It was expected that the water content of the seeds would be maintained without any large fluctuations, since the temperature and relative humidity are constant in that environment: any increase in water content presented by the seeds may be due to a possible change in the relative humidity occurring during storage. According to Bragantini (2005), products tend to release water into, or absorb water from, the surrounding environment until reaching an equilibrium, whenever the relative humidity of the storage environment changes. In the refrigerator, the multilayered paper packaging best maintained this level throughout the storage period. The different types of packaging used resulted in different responses when assessing the moisture content of the seeds, being influenced by the permeability characteristics of each type (CARDOSO et al., 2012). In the freezer, the black polyethylene was better at preserving the initial water content of the seeds during storage (Figure 1), a fact that can be explained by the impermeability of this packaging. The use of impermeable packaging ensures that the moisture content is maintained, being suitable for longer periods of conservation, with less risk of loss in the physiological quality of the seeds through deterioration (CORLETT et al., 2007). Azeredo et al. (2005), when storing peanut seeds in paper packaging under non-controlled conditions and in a dry cold room, observed that the water content of the seeds fluctuated around $6-8 \%$.

The seeds kept in the natural environment showed a sharp reduction in germination from the third month of storage, fully losing their germinating power in the sixth month, regardless of the type of packaging used for storage (Figure 2).

Uncontrolled conditions of temperature and relative humidity during the storage period result in a

Figure 2 - Germination (\%) of sunflower seeds kept in different environments and packaging during 12 months of storage

\section{Natural enviorment}

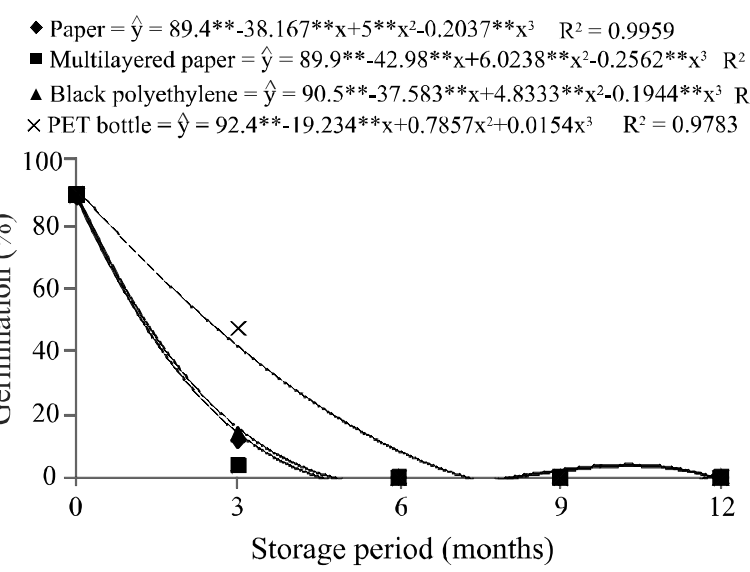

Refrigerator

- Paper $=\hat{y}=92.9^{* *}-4.9881 \mathrm{x}+0.9365 \mathrm{x}^{2}-0.0463 \mathrm{x}^{3} \quad \mathrm{R}^{2}=0.9965$

Multilayered paper $=\hat{y}=93.4 * *-8.0754 * * x+1.6984 * * x^{2}-0.0895 * * x^{3} \quad R^{2}=0.8272$

A Black polyethylene $=\hat{y}=93.4^{* *}-0.6 x \quad R^{2}=0.9878$

$\times$ PET bottle $=\hat{\mathrm{y}}=92.5^{* *}-4.5833 \mathrm{x}+1.1111 \mathrm{x}^{2}+0.0648 \mathrm{x}^{3} \quad \mathrm{R}^{2}=0.75$

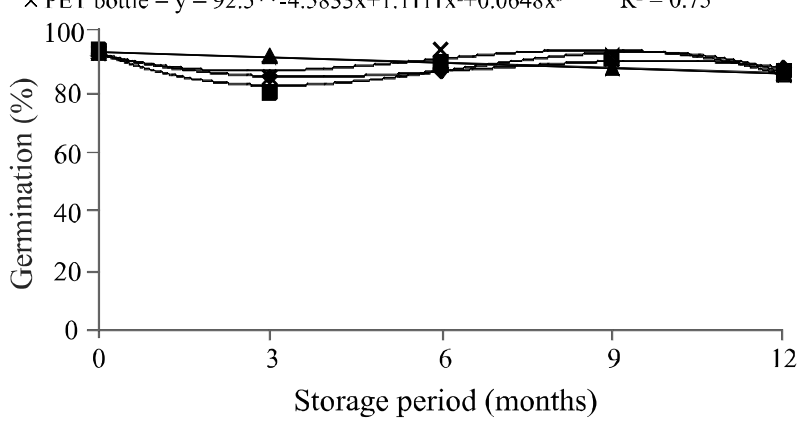

Dry cold room

- Paper $=\hat{\mathrm{y}}=91.7 * *-24.925 * * \mathrm{x}+5.5794 * * \mathrm{x}^{2}-0.2994 * * \mathrm{x}^{3} \quad \mathrm{R}^{2}=0.7362$

Multilayered paper $=\hat{y}=93.4 * *-4.5595 x+0.7063 x^{2}-0.0278 x^{3} \quad R^{2}=0.7028$

॥ Black polyethylene $=\hat{y}=94.1 * *-1.4405 x+0.1825 * * x^{2}-0.0093 x^{3} \quad R^{2}=0.9173$

$\times$ PET bottle $=\hat{y}=92.3 * *-1.377 x+0.3254 x^{2}-0.0216 x^{3} \quad R^{2}=0.765$

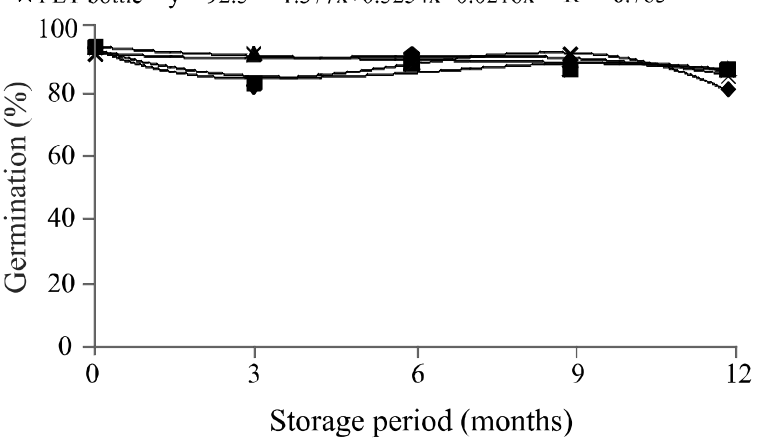

Freezer

- Paper $=\hat{\mathrm{y}}=92.7 * *-4.1587 \mathrm{x}+1.0317 \mathrm{x}^{2}-0.0617 \mathrm{x}^{3} \quad \mathrm{R}^{2}=0.9398$

Multilayered paper $=\hat{y}=91.3 * *-0.9802 x+0.0238 x^{2}-0.0031 x^{3} \quad R^{2}=0.6435$

A Black polyethylene $=\hat{y}=91.9^{* *}+1.2857 \mathrm{x}-0.3571 \mathrm{x}^{2}+0.0185 \mathrm{x}^{3} \quad \mathrm{R}^{2}=0.9973$

$\times$ PET bottle $=\hat{y}=93.4 * *+2.9246 x-0.9683 x^{2}+0.0586 x^{3} \quad R^{2}=0.7902$

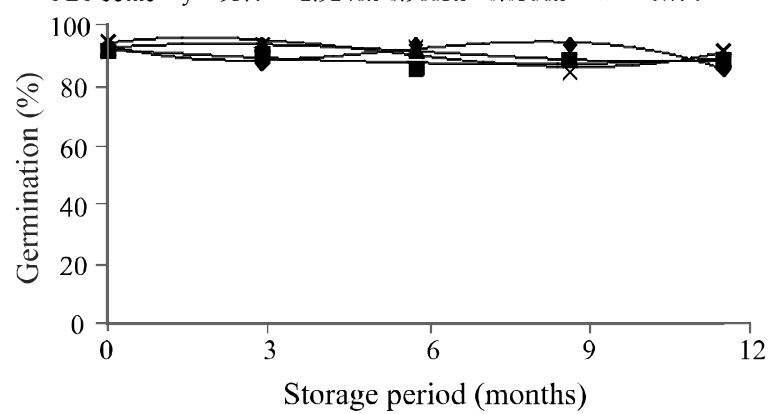


rapid reduction in germination (CARDOSO et al., 2012). Theophilus et al. (2004), evaluating physiological quality of seeds of Myracrodruon urundeuva Allemão, an oilseed plant, showed that seeds of this species lose their viability and vigour from the ninth month of storage when kept in a natural environment. In the dry cold room, the refrigerator and freezer, germination of sunflower seeds remained over $80 \%$ throughout the storage period.

These results show that low temperature environments are more suitable for the conservation of seeds of this species when compared to a natural environment, resulting in greater values for germination. Low temperatures reduce the rate of chemical reactions, and consequently of respiration, benefiting conservation of the seeds (MARCOS FILHO, 2005). Oliveira et al. (2009), when evaluating physiological quality in the sesame, concluded that seed quality was not altered after nine months of storage under the conditions of Campina Grande in the state of Paraíba, or in a cold room.

Analysing the physiological potential of sunflower seeds stored in different environments and packaging (Figure 3), it can be seen from the first germination count data, that there was a sharper reduction during the $3 \mathrm{rd}$ month of storage in the germination of those seeds packed in paper and stored in the refrigerator and freezer. The seeds tend to absorb water and deteriorate more easily when stored in packaging that allows the exchange of water vapour with the atmosphere. According to Marcos Filho (2005), a low germination rate is indicative of a low physiological potential, being one of the most obvious manifestations of the deterioration process. In the dry cold room, all packaging showed similar behaviour, with no large reductions in the percentage

Figure 3 - First germination count (\%) of sunflower seeds kept in different environments and packaging during 12 months of storage

\section{Natural enviorment}

- Paper $=\hat{\mathrm{y}}=88.2^{* *}-39.02 * * \mathrm{x}+5.2262 * * \mathrm{x}^{2}-0.216^{* *} \mathrm{x}^{3} \quad \mathrm{R}^{2}=0.9939$

- Multilayered paper $=\hat{\mathrm{y}}=88.8^{* *}-43.563^{* *} \mathrm{x}+6.1905^{* *} \mathrm{x}^{2}-0.2654^{* *} \mathrm{x}^{3} \quad \mathrm{R}^{2}=0.985$

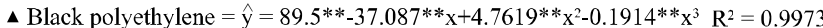

$\times$ PET bottle $=\hat{y}=91.2^{* *}-20.357^{* *} x+1.0714 x^{2} \quad R^{2}=0.9821$

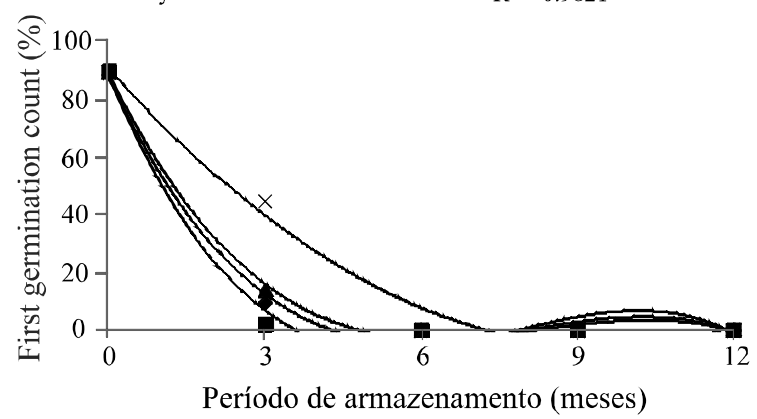

Refrigerator

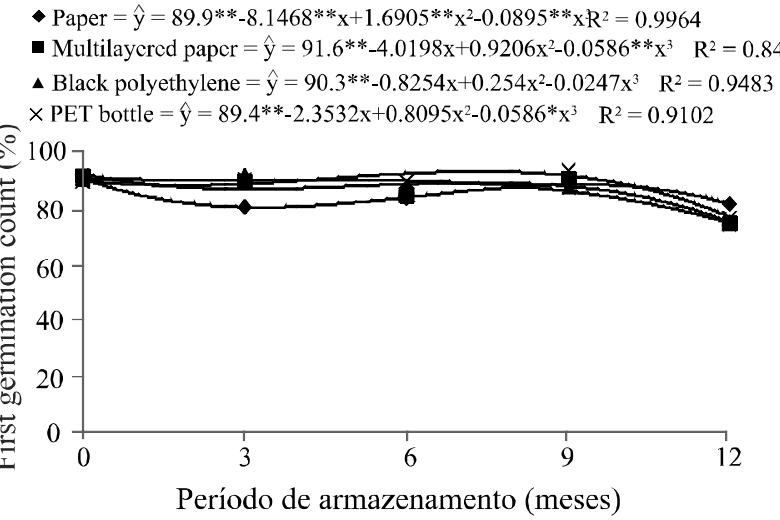

Dry cold room

- Paper $=\hat{\mathrm{y}}=90.3 * *-2.5397 * * \mathrm{x}+0.8413 * * \mathrm{x}^{2}-0.0617 * * \mathrm{x}^{3} \mathrm{R}^{2}=0.9627$

Multilayered paper $=\hat{y}=90.3 * *-4.6468 x+0.9683 * x^{2}-0.0525 * x^{3} \quad R^{2}=0.544$

A Black polyethylene $=\hat{y}=89.4 * *-1.8373 * * x+0.4841 * x^{2}-0.034 * * x^{3} \quad R^{2}=0.8677$

$\times$ PET bottle $=\hat{y}=91.1^{* *}-4.254 x+0.9841 x^{2}-0.0617^{*} x^{3} \quad R^{2}=0.9939$

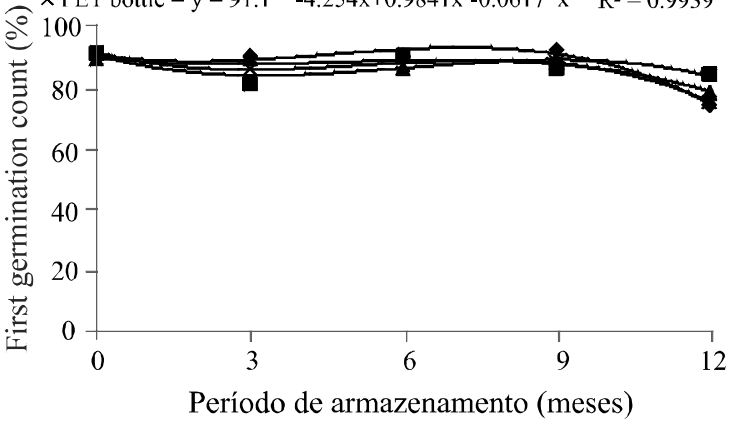

Freezer

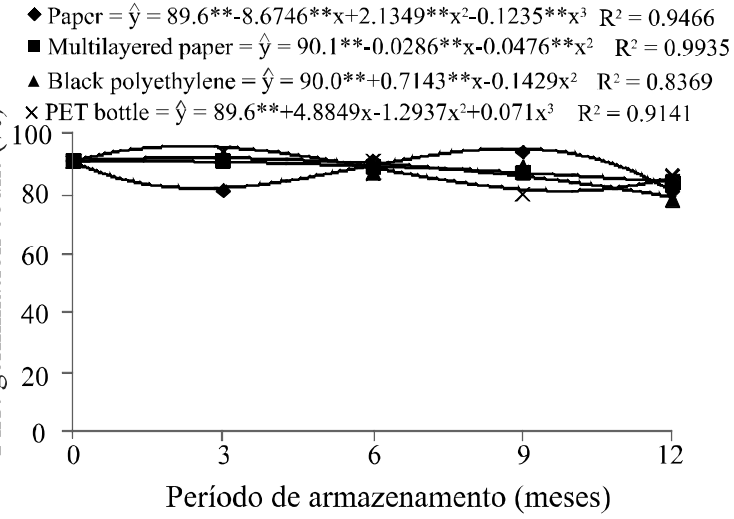


of germination. Abreu et al. (2011), working on the evaluation of sunflower seeds stored at different temperatures, found that at a temperature of $10{ }^{\circ} \mathrm{C}$ (cold room), seed vigour was maintained during the twelve months of storage without any significant change. Seeds kept in paper bags, multilayered paper, black polyethylene and PET bottles completely lost their vigour when stored in the natural environment (Figure 3 ). Humidity and temperature have a great influence on seed conservation, influencing the biochemical reactions that regulate the metabolism involved in that process (MARTINS; LAGO, 2008): these factors being determined by the packaging and storage conditions. Machado et al. (2010), storing seeds of the castor bean in a natural environment, observed a reduction in the rate of germination of these seeds by the sixth month of storage.

The conditions of stress imposed by accelerated ageing significantly reduced the number of normal seedlings after three months of storage, when stored in a natural environment (Figure 4). Queiroga (1992) found that accelerated ageing significantly reduced the germination of such seeds after they had been stored for six months in the laboratory. In the dry cold room, seeds packed in black polyethylene showed the greatest reductions in vigour, reaching $63 \%$ in the ninth month of storage (Figure 4).

For accelerated ageing, the seeds gain moisture under high temperatures during the initial period of the test, with different rates of moisture gain observed between batches of the same species, resulting in different degrees of ageing for the same period of time (KRZYZANOWSKI, 1999). Seeds stored in the refrigerator or freezer showed no major reductions in vigour regardless of the type of packaging used. Freitas et al. (2000) observed a decrease in vigour with the ageing test in cotton seeds during storage.

For the emergence speed index of sunflower seedlings, it was found that storage of the seeds in

Figure 4 - Accelerated ageing (\%) of sunflower seeds kept in different environments and packaging during 12 months of storage

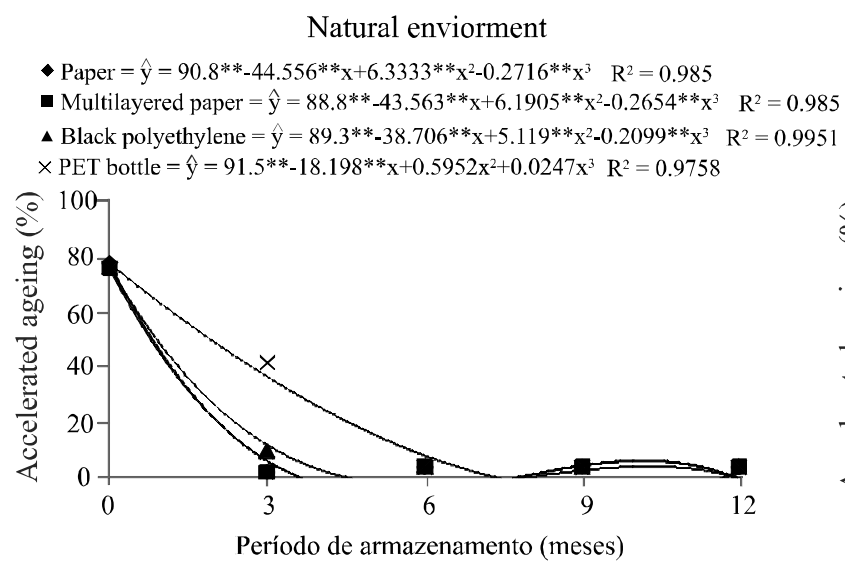

Refrigerator

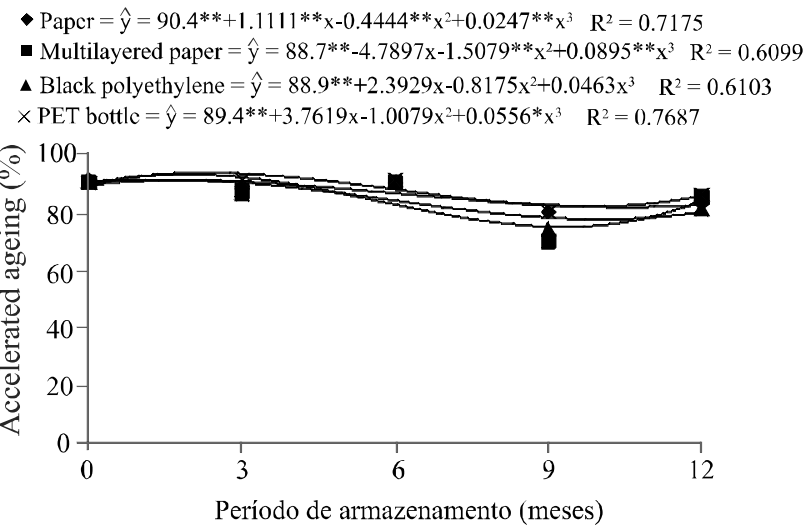

Dry cold room

- Paper $=\hat{y}=90.6 * *-4.2302 * * x+0.5794 * x^{2}-0.0247 x^{3} \quad R^{2}=0.8805$

- Multilayered paper $=\hat{y}=89.3 * *-0.4325 x-0.0635 x^{2}+0.0031 x^{3} \quad R^{2}=0.6472$

$\Delta$ Black polyethylene $=\hat{\mathrm{y}}=90.5 * *+3.1865 * \mathrm{x}-1.6984 * \mathrm{x}^{2}+0.1142 * * \mathrm{x}^{3} \mathrm{R}^{2}=0.9666$

$\times$ PET bottle $=\hat{y}=89.5^{* *+2}+4048 \mathrm{x}-0.4921 \mathrm{x}^{2}+0.0185 \mathrm{x}^{3} \quad \mathrm{R}^{2}=0.8832$

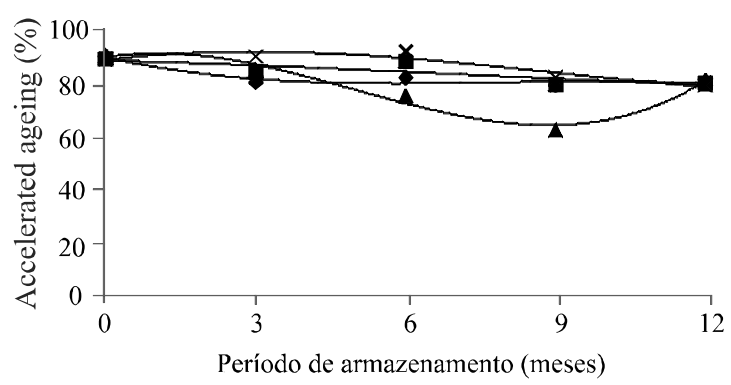

Freezer

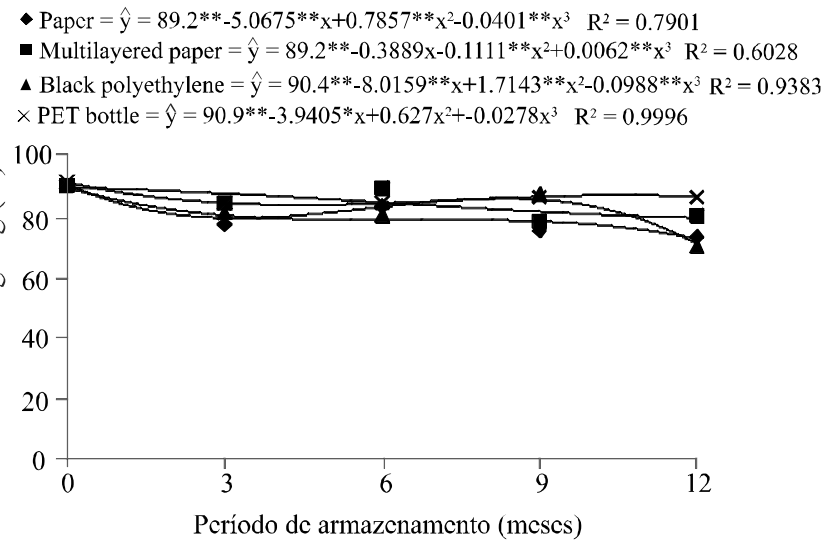


a natural environment, independent of the type of packaging used, completely nullified seed vigour from the sixth month of storage (Figure 5). Regardless of packaging, all the seeds stored in the dry cold room, refrigerator and freezer showed similar behaviour and values, with a reduction being observed in the rate of emergence over nine months of storage, and an increase in the twelfth month (Figure 5).

Results for the dry cold room can be explained by the environment where the tests were carried out not having any local control of temperature or relative humidity, with sowing being done at different times of the year. Guedes et al. (2012), evaluating the storage of seeds of the mastic tree in different packaging and environments, observed a sharper reduction in the speed of emergence of seeds stored in the laboratory, where the climatic conditions are not controlled. According to Nakagawa (1999), seed vigour may also be related to such characteristics of the seedlings as growth and speed of emergence, among others.
When evaluating vigour by the dry weight of the seedlings, it was found that there was a decrease in dry weight over nine months of storage, and an increase in the 12th month, for seeds stored in controlled environments (dry cold room, fridge and freezer)

According to Antonello et al. (2009) this result does not reflect the usual behaviour of stored seeds, where it is expected that evaluation of the characteristics of the seedlings at the end of the storage period should show a decrease caused by the loss of seed vigour over time. In the natural environment, the seedlings showed a reduction in dry weight by the third month of storage, and a sharp drop at six months. Bezerra et al. (2004), studying the physiological quality of moringa seeds, found that in a natural environment the seedlings maintained their initial dry weight for up to six months of storage, showing a drastic drop at 24 months, whereas in a controlled environment (cold room) variation in the dry mass of the seedlings was less pronounced.

Figure 5 - Emergence speed index of sunflower seeds kept in different environments and packaging during 12 months of storage

\section{Natural environment}

- Paper $=\hat{\mathrm{y}}=4.812^{* *}-2.2969^{* *} \mathrm{x}+0.3217^{* *} \mathrm{x}^{2}-0.0137^{* *} \mathrm{x}^{3} \quad \mathrm{R}^{2}=0.9878$

Multilayered paper $=\hat{\mathrm{y}}=4.861 * *-2.3325 * * \mathrm{x}+0.3276^{* *} \mathrm{x}^{2}-0.014 * * \mathrm{x}^{3} \mathrm{R}^{2}=0.9872$

$\Delta$ Black polyethylene $=\hat{\mathrm{y}}=4.879^{* *}-1.961^{* *} \mathrm{x}+0.2464^{* *} \mathrm{x}^{2}-0.0098^{* *} \mathrm{x}^{3} \mathrm{R}^{2}=0.9984$

$\times$ PET bottle $=\hat{y}=4.785 * *-2.0671 * * x+0.2729 * * x^{2}-0.0112 * x^{3} R^{2}=0.9953$

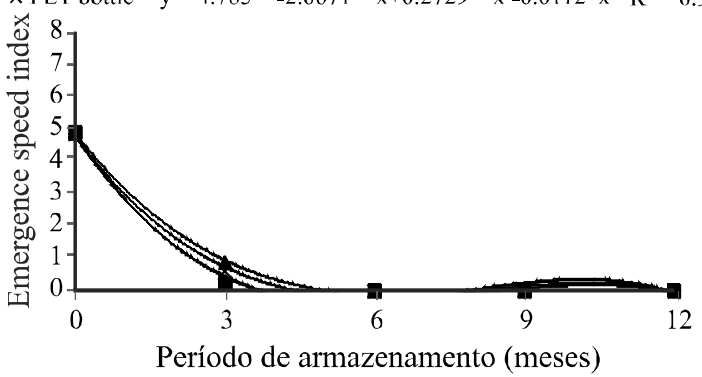

Refrigerator

- Paper $=\hat{y}=4.821 * *-0.1959 x-0.1459 * * x^{2}+0.0127 * * x^{3} \quad R^{2}=0.9665$

- Multilayered paper $=\hat{y}=4.614^{* *}-0.1679 \mathrm{x}-0.1206^{* *} \mathrm{x}^{2}-0.011^{* *} \mathrm{x}^{3} \quad \mathrm{R}^{2}=0.9761$

$\Delta$ Black polyethylenc $=\hat{y}=4.661^{* *}-0.0431 \mathrm{x}-0.159^{* *} \mathrm{x}^{2}+0.0131^{* *} \mathrm{x}^{3} \mathrm{R}^{2}=0.9484$

$\times$ PET bottle $=\hat{y}=4.579^{* *}-0.1919 x-0.2007^{* *} x^{2}-+0.015^{* *} x^{3} \quad R^{2}=0.9029$

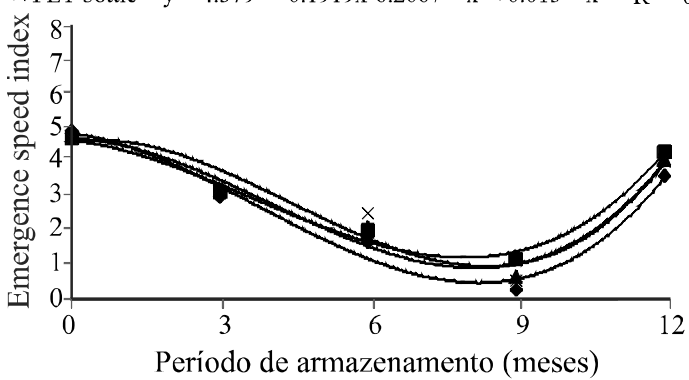

Dry cold room

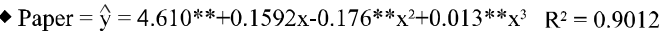

- Multilayered paper $=\hat{y}=4.866^{* *}-0.1545 \mathrm{x}-0.1453^{* *} \mathrm{x}^{2}+0.0126^{* *} \mathrm{x}^{3} \quad \mathrm{R}^{2}=0.9824$

A Black polyethylene $=\hat{y}=4.773 * *-0.1348 x-0.1298 * * x^{2}+0.0113 * * x^{3} \quad R^{2}=0.8881$

$\times$ PET bottle $=\hat{y}=4.486^{* *}-0.2429 x-0.0942 * x^{2}+0.0091 * * x^{3} \quad R^{2}=0.8568$

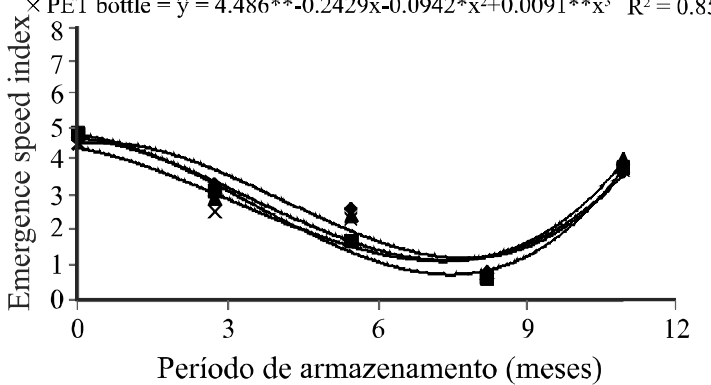

Freezer

- Paper $=\hat{\mathrm{y}}=4.664 * *+0.0021 \mathrm{x}-0.1345^{* *} \mathrm{x}^{2}+0.0104 * * \mathrm{x}^{3} \quad \mathrm{R}^{2}=0.898$

- Multilayered paper $=\hat{\mathrm{y}}=4.647 * *-0.2454 \mathrm{x}-0.0942 * * \mathrm{x}^{2}-0.0092 * * \mathrm{x}^{3} \quad \mathrm{R}^{2}=0.8777$

\ Black polyethylenc $=\hat{y}=4.910^{* *}-0.2907 x-0.0862 x^{2}+0.0083 * * x^{3} \quad R^{2}=0.9698$

$\times$ PET bottle $=\hat{y}=4.658 * *-0.3645 x-0.0713 x^{2}+0.0079 * * x^{3} \quad R^{2}=0.9293$

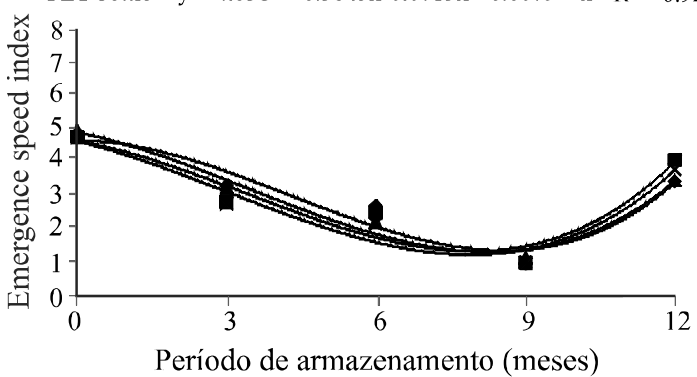


Figure 6 - Seedling dry weight $(\mathrm{g})$ of sunflower seeds kept in different environments and packaging during 12 months of storage

Natural environment

- Paper $=\hat{\mathrm{y}}=0.672 * *-0.3211 \mathrm{x}+0.045^{* *} \mathrm{x}^{2}-0.0019 * * \mathrm{x}^{3} \quad \mathrm{R}^{2}=0.9876$

Multilayered paper $=\hat{y}=0.673^{* *}-0.3103^{* *} \mathrm{x}+0.0426^{* *} \mathrm{x}^{2}-0.0018^{* *} \mathrm{x}^{3} \mathrm{R}^{2}=0.9908$

\ Black polyethylene $=\hat{\mathrm{y}}=0.683^{* *}-0.3099^{* *} \mathrm{x}+0.0421^{* *} \mathrm{x}^{2}-0.0018^{* *} \mathrm{x}^{3} \mathrm{R}^{2}=0.9921$

$\times$ PET bottle $=\hat{y}=0.664^{* *}-0.2946^{* *} \mathrm{x}+0.039^{* *} \mathrm{x}^{2}-0.0016^{*} \mathrm{x}^{3} \quad \mathrm{R}^{2}=0.9937$

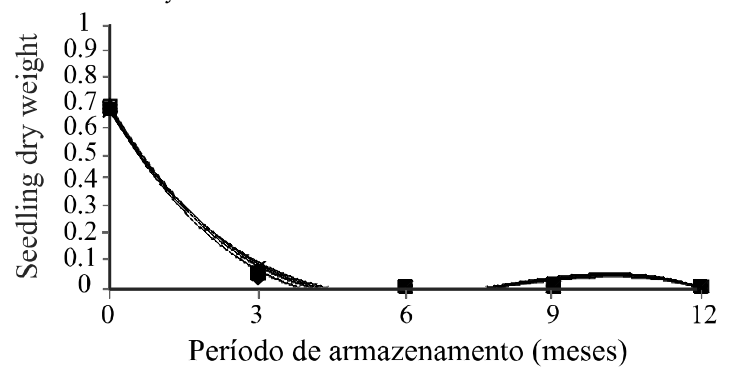

Refrigerator

- Paper $=\hat{\mathrm{y}}=0.655^{* *}+0.0984^{* *} \mathrm{x}+0.0465^{* *} \mathrm{x}^{2}+0.0031^{* *} \mathrm{x}^{3} \quad \mathrm{R}^{2}=0.9914$

Multilayered paper $=\hat{\mathrm{y}}=0.686^{* *+0}+0.0655^{*} \mathrm{x}-0.0375^{* *} \mathrm{x}^{2}+0.0026^{* *} \mathrm{x}^{3} \quad \mathrm{R}^{2}=0.9878$

$\triangle$ Black polyethylene $=\hat{y}=0.674 * *+0.0122 \mathrm{x}-0.0211^{* *} \mathrm{x}^{2}+0.0016^{* *} \mathrm{x}^{3} \quad \mathrm{R}^{2}=0.9913$

$\times$ PET bottle $=\hat{y}=0.672 * *+0.0988^{* *} \mathrm{x}-0.0425^{* *} \mathrm{x}^{2}+0.0028^{* *} \mathrm{x}^{3} \quad \mathrm{R}^{2}=0.9982$

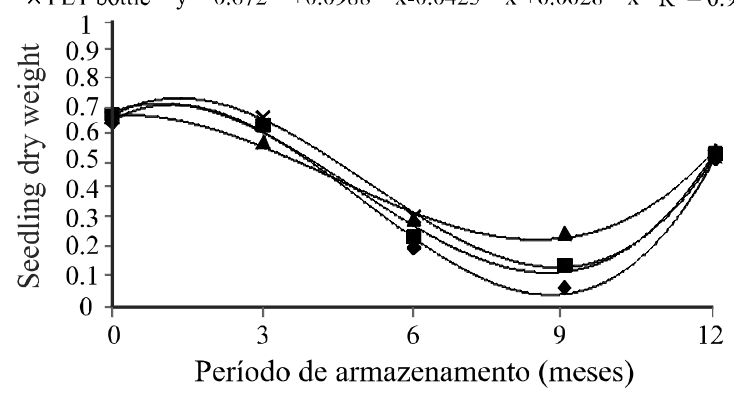

\section{CONCLUSION}

A natural environment is not suitable for the storage of sunflower seeds. Sunflower seeds remain viable for 12 months when stored in a dry cold room, refrigerator or freezer, irrespective of the type of packaging used.

\section{REFERENCES}

ABREU, A. S. et al. Teste de condutividade elétrica na avaliação de sementes de girassol armazenadas sob diferentes temperaturas. Revista Brasileira de Sementes, v. 33, n. 04, p. 635-642, 2011.

ABUD, H. F. et al. Armazenamento de sementes de xique-xique. Revista Brasileira de Sementes, v. 34, p. 473-479, 2012.

AGUIAR, I. B. Conservação de sementes. In: SILVA, A.; PIÑARODRIGUES, F.C.M.; FIGLIOLIA, M.B. (Coord.). Manual técnico de sementes florestais. São Paulo: Instituto Florestal, 1995. p. 33-44.

ALMEIDA, F. A. C. et al. Estudo de técnicas para o armazenamento de cinco oleaginosas em condições
Dry cold room

- Paper $=\hat{y}=0.666^{* *}+0.0654 * * x-0.0316 x^{2}+0.0021 * * x^{3} \quad R^{2}=0.9939$

Multilayered paper $=\hat{y}=0.683^{* *+0}+0.0834 * x-0.0386^{* *} \mathrm{x}^{2}+0.0025^{* *} \mathrm{x}^{3} \quad \mathrm{R}^{2}=0.9861$

$\Delta$ Black polyethylene $=\hat{y}=0.71^{* *}+0.165^{* *} \mathrm{x}-0.0594^{* *} \mathrm{x}^{2}+0.0037^{* *} \mathrm{x}^{3} \quad \mathrm{R}^{2}=0.9782$ $\times$ PET bottle $=\hat{y}=0.691 * *+0.0796 * x-0.0381 * * x^{2}+0.0025^{* *} x^{3} \quad R^{2}=0.9994$

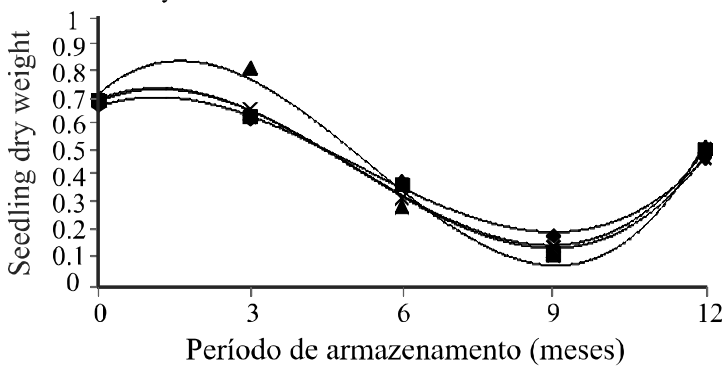

Freezer

- Paper $=\hat{\mathrm{y}}=0.621^{* *+0}+1047 \mathrm{x}-0.0368^{* *} \mathrm{x}^{2}+0.0023^{* *} \mathrm{x}^{3} \quad \mathrm{R}^{2}=0.9292$

- Multilayered paper $=\hat{y}=0.69 * *+0.0406 * x-0.03 * * x^{2}-0.0022 * * x^{3} \quad R^{2}=0.9615$

B Black polyethylene $=\hat{y}=0.694 * *+0.0759 * x-0.0348^{* *} \mathrm{x}^{2}+0.0023^{* *} \mathrm{x}^{3} \quad \mathrm{R}^{2}=0.9112$

$\times$ PET bottle $=\hat{y}=0.718^{* *}-0.0263 x-0.0112 x^{2}+0.001 x^{3} \quad R^{2}=0.8198$

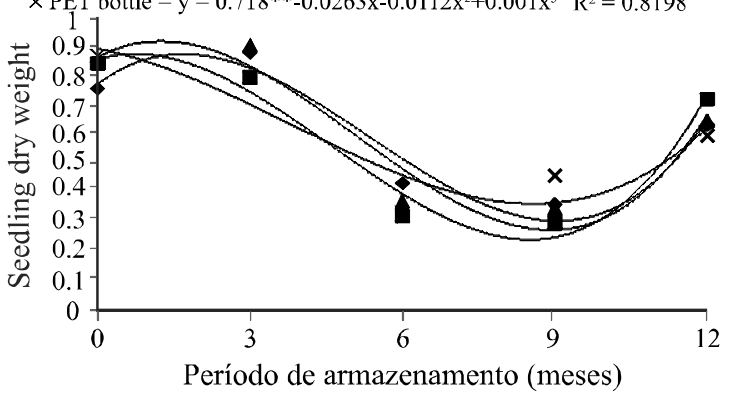

ambientais e criogênicas. Revista Brasileira de Produtos Agroindustriais, v. 12, p. 189-202, 2010.

ANTONELLO, L. M. et al. Influência do tipo de embalagem na qualidade fisiológica de sementes de milho crioulo. Revista Brasileira de Sementes (Impresso), v. 31, p. 75-86, 2009.

AZEREDO, G. A. et al. Conservação de sementes de amendoim (Arachis hypogae L.) em função do beneficiamento, embalagem e ambiente de armazenamento.Pesquisa Agropecuária Tropical, v. 35, n. 01, p. 37-44, 2005.

BRAGANTINI, C. Alguns aspectos do armazenamento de sementes e grãos de feijão. Santo Antônio de Goiás. Embrapa Arroz e Feijão. 2005. 28 p.

BEZERRA, A. M. E. et al. Avaliação da qualidade das sementes de Moringa oleifera Lam. Durante o armazenamento. Ciência e Agrotecnologia, v. 28, n. 06, p. 1240-1246, 2004.

CARDoso, R. B.; BinOtTI, F. F. S.; CARdoso, E. D. Potencial fisiológico de sementes de crambe em função de embalagens e armazenamento. Pesquisa Agropecuária Tropical, v. 42, p. 272-278, 2012. 
CARVAlHO, N. M.; NAKAGAWA, J. Sementes: ciência, tecnologia e produção. 4 ed. Jaboticabal: FUNEP, 2000. $588 \mathrm{p}$.

CORLETT, F. M. F.; BARROS, A. C. S.A.; VILLELA, F. A. Qualidade fisiológica de sementes de urucum armazenadas em diferentes ambientes e embalagens. Revista Brasileira de Sementes, v. 29, n. 2, p. 148-158, 2007.

FREITAS, R. A. et al. Qualidade fisiológica e sanitária de sementes de algodão durante o armazenamento. Revista Brasileira de Sementes, v. 22, n. 02, p. 94-101, 2000.

GOMES, D. P.; et al. Qualidade fisiológica e sanitária de sementes de girassol cultivadas em Timon, MA. Summa Phytopathologica, v. 32, p. 291/3-292, 2006.

GUEDES, R. S. et al. Armazenamento de sementes de Myracrodruon urundeuva Fr. All. em diferentes embalagens e ambientes. Revista Brasileira de Plantas Medicinais, v. 14, n. 01, p. 68-75, 2012.

KRZYZANOWSKI, F. C; VIEIRA, R. D; FRANÇA NETO, J. B. Vigor de Sementes. Conceitos e Teses. Londrina, 1999b. p. 3.1-3.24.

MAGUIRE, J.D. Speed of germination-aid in selection and evaluation for seedlig emergence and vigor. Crop Science, v. 2 , n. 1 , p. $176-177,1962$.

MARCOS FILHO, J. Fisiologia de sementes de plantas cultivadas. Piracicaba: FEALQ, 2005. 495p.

MARCOS-FILHO, J. Teste de envelhecimento acelerado. In: KRZYZANOWSKI, F.C.; VIEIRA, R.D.; FRANÇA NETO, J.B.. (Ed.). Vigor de sementes: conceitos e testes. Londrina: ABRATES, 1999. p. 3-21.
MARTINS, L.; LAGO, A. A. Conservação de semente de Cedrela fissilis: teor de água da semente e temperatura do ambiente. Revista Brasileira de Sementes, v. 30, n. 1, p. 161-167, 2008.

MACHADO, C. G. et al. Posição do racemo e do fruto na qualidade fisiológica de sementes de mamona durante o armazenamento. Semina: Ciências Agrárias, v. 31, p. 301312, 2010.

NAKAGAWA, J. Testes de vigor baseados no desempenho das plântulas. In: KRZYZANOSKI, F. C.; VIEIRA, R.D.; FRANÇA NETO, J.B. (Ed.). Vigor de sementes: conceitos e testes. Londrina: ABRATES, 1999. p. 2.1-2.24.

OLIVEIRA, EDINETE MARIA; COSTA, C.C. Qualidade fisiológica de gergelim armazenado em diferentes condições de conservação. Engenharia Ambiental, v. 6, p. 3-14, 2009.

QUEIROGA, V. P. Teste de envelhecimento precoce e condutividade elétrica em sementes de girassol (Helianthus annuus, L.). Agropecuária Técnica, v. 13, n. 1/2, 1992.

PORTO, W. S.; CARVALHO, C. G. P.; PINTO, R. J. B. Adaptabilidade e estabilidade como critérios para seleção de genótipos de girassol. Pesquisa Agropecuária Brasileira, v. 42, n. 4, p. 491-499, abr. 2007.

TEÓFILO, E. M. et al. Qualidade fisiológica de sementes de aroeira (myracrondrun urundeuva ALLEMÃO) em função do tipo de embalagem, ambiente e tempo de armazenamento. Revista de Ciência Agronômica, v. 35, n. 2, p. 371-376, 2004.

TONIN, G. A.; PEREZ, S. C. J. G de A. Qualidade fisiológica de sementes de Ocotea porosa (NEES ET MARTIUSEX. NEES) após diferentes condições de armazenamento e semeadura. Revista Brasileira de Sementes, v. 28, n. 2, p. 26- 33, 2006. 